\title{
The Role of Water and Lithology on the Deformation and Failure of an Anaclinal Rock Slope in a Hydropower Reservoir
}

\author{
Ming-liang Chen, ${ }^{1}$ Peng-fei Lv, ${ }^{2}$ Wen-ze Nie, ${ }^{3}$ Chang-ming Tan, ${ }^{4}$ Zhi-hua Bai, ${ }^{5}$ Yong Liao, ${ }^{2}$ \\ and Jia-wen Zhou $\mathbb{D}^{1}$ \\ ${ }^{1}$ State Key Laboratory of Hydraulics and Mountain River Engineering, Sichuan University, Chengdu 610065, China \\ ${ }^{2}$ Dadu River Hydropower Development Company, Ltd., Chengdu 610016, China \\ ${ }^{3}$ Power China Guiyang Engineering Corporation Limited, Guiyang 550081, China \\ ${ }^{4}$ Sichuan Highway Planning, Survey, Design and Research Institute Ltd., Chengdu 610041, China \\ ${ }^{5}$ College of Water Resource and Hydropower, Sichuan University, Chengdu 610065, China \\ Correspondence should be addressed to Jia-wen Zhou; jwzhou@scu.edu.cn
}

Received 5 July 2020; Revised 13 August 2020; Accepted 19 August 2020; Published 28 August 2020

Academic Editor: Chong Xu

Copyright ( 92020 Ming-liang Chen et al. This is an open access article distributed under the Creative Commons Attribution License, which permits unrestricted use, distribution, and reproduction in any medium, provided the original work is properly cited.

\begin{abstract}
A series of settlement, cracking, and collapse of the Zhengjiaping slope has been increasingly developing since October 2015 during impoundment at the Dagangshan Hydropower Station. It is a dangerous signal, which means thatlandslide potential will be existed for the Zhengjiaping slope and poses greatthreat to the operation of hydropower station and traffic safety. Related slope protection measures and research studies have been implemented accordingly in the Zhengjiaping slope to prevent and control adverse influences on property security and human life in the reservoir area. In order to understand the geological and hydrological settings of the Zhengjiaping slope and its surroundings, a field investigation was carried out to determine the lithological composition and toppling/sliding deformation characteristics using exploratory adit and site boreholes. The large deformation process in the apparently deformed area was analyzed using borehole inclinometers and global navigation satellite systems (GNSS). It was found that the apparently deformed area zone was characterized by crushed rock masses, with only a small amount of slope deposits and the sliding deformation occurring in Zone I. The deformation process of the reservoir landslide was considered to be a complex integration of the geological effects of various adverse factors. Impoundment and heavy rainfall are the direct causes of sliding deformation. During the preparation of the basic conditions for sliding, lithology, tectonic activity, and artificial disturbances play an important role, including the sliding mass and the sliding surface zone.
\end{abstract}

\section{Introduction}

Reservoir landslides are various types of gravitational mass movements of the earth's surface that occur on the banks of the reservoir area $[1,2]$. According to a field investigation, the origin of reservoir landslides is complicated and multiple: (i) slope deposits by alluviation, proluvial action, colluviation, ancient landslide action, or hybrid origin; (ii) broken rock mass by weathering, runoff erosion, tectonic activities, seismic load, artificial disturbances; and (iii) rock mass with the involvement of soft interlayer. Furthermore, differences also exist in proportion of the shallow earth with deformation occurring in the mass above the sliding surface. Integral failure or disintegrated failure has been ever presented in previous occurrences of reservoir landslides because of the differences in the amount and development degree of the sliding surface zone $[3,4]$.

The preparation and occurrence of reservoir landslides is a very complex and dynamic process that is a long-playing integration of multiple factors. It is generally accepted that impoundment, reservoir level fluctuations, rainfall, and artificial disturbances are the main contributing factors [5-10]. There have been many studies focusing on the origin of reservoir landslides from slope deposits [11-14]. For slope 
deposits, impoundment and the coupling of heavy rainfall and reservoir level drawdown during the operational period weakens the physical and mechanical properties of the slope material, forms transient seepage, and changes the mechanical behavior, which are highly conducive to the occurrence of reservoir landslides [15]. Understanding how adverse factors contribute to the formation of sliding conditions for the earth's surface and the causative factors that cause sliding deformation is particularly important for landslide prevention and mitigation. A comprehensive understanding of reservoir landslides is important for predicting or identifying precursor phenomena to large reservoir landslides and further generating a series of effective prevention and control measures. Few articles have made specific reference to reservoir rock landslides, but previous studies have made important contributions to the understanding of different aspects related to general rock slide failures. From these studies, there are implications for the understanding of reservoir landslides. Field investigation of geological conditions and characterization of the velocity, distribution, and evolution of movement are fundamental tasks for understanding unstable slope behavior and potential failure [16-18]. According to many cases, topography, lithology, geological structure, and tectonic activity play an important role in the development of slope instability, which should usually be a long-term evolutionary process from its inception to catastrophic failure [19]. For rock slopes with potential geologic hazards, the temporal evolution of geomorphology and structure, as well as the influence of lithologic differences and tectonic activity on slope deformation, are of great interest [20-25]. For rock slopes that have undergone landslides, mathematical description of the dynamic mechanisms and kinematic processes of disaster triggers is a key point [26-32]. To prevent the occurrence of rock slides, methods for evaluating the stability of slopes in reservoir areas have been investigated, such as developmental characterization of cracked rock masses, reliability analysis of rock slopes, or predictive models based on monitoring or statistical analysis [33-39].

Reservoir landslides, as a notable geological hazard in reservoir areas, are characterized by their large scale and widespread impact. Reservoir landslides pose a great threat to human beings, environmental stability, property safety, and reservoir operation $[2,15]$. The reservoir area in southwest China has steep topography and fragile geology, with broken rock masses in shallow earth and quaternary accumulations covered. The complex geological conditions of the reservoir area are not conducive to slope stability. With the gradual development of cascading hydropower stations, the frequent occurrence of reservoir landslides has seriously threatened the safety of power station buildings and the stability of the reservoir area slopes. At present, the study of reservoir landslides has become one of the important tasks of hydropower development in southwest China.

This paper takes the Zhengjiaping slope as an example to study the deformation characteristics and mechanism of the rock slope deformation occurring in the reservoir area. The geological conditions, lithologic composition, and toppling deformation characteristics revealed by the field survey are the basis for understanding the deformation behavior of the Zhengjiaping slope. The monitoring mainly includes lateral displacement and surface point displacement. The results of lateral displacement and geologic cognition can confirm the existence of basic conditions for sliding deformation, including sliding mass and sliding surface zone. The analysis of surface point displacement is used to identify the factors involved in the deformation of the Zhengjiaping slope, including the adverse factors in the preparation of deformation and causative factors. Then, the influence of unfavorable factors on the process of formation and evolution of sliding deformation is discussed in order to refine some peculiarities of rock slides in the reservoir area.

\section{Study Area}

The Zhengjiaping slope is located in Xingfu Village, Tianwan Township, Sichuan Province, in the central alpine region between the Tibetan Plateau and the Sichuan Basin in southwestern Sichuan Province, as shown in Figure 1(a). The Zhengjiaping slope is located upstream of Dagangshan Power Station on the right bank of the Dadu River, about $15 \mathrm{~km}$ from the dam site of Dagangshan Power Station,as shown in Figure 1(b). According to the relationship between rock inclination and slope ([40], Figure 2), the Zhengjiaping slope belongs to the anaclinal slope. The slope of the Zhengjiaping side slope is $30^{\circ}-40^{\circ}$, and the surface is mostly covered by accumulated deposits.

Figure 3(a) shows the lithology of the Zhengjiaping slope and the surrounding area. The evident deformation zone in the Zhengjiaping slope was developed in the stratified sandstone and shale of the Baiguowan Formation. The Baiguowan Group is distributed between the East Branch Fault (F1) and the West Branch Fault (F2) of the Dadu River Fracture Zone. The lithology of the Baiguowan Group is mostly siltstone mudstone, with gray sandstone and grayblack carbonaceous shale in the interlayer. The Chengjiang stage, characterized by granite, is distributed on the left bank of the Dadu River and the footwall of the East Branch Fault of the Dadu River Fracture Zone on the right bank. The Zhongdian period is characterized by tonalite gneiss and diorite gneiss, which are distributed in the footwall of the West Branch Fault (F2) of the Dadu River Fracture Zone. The area below $1130 \mathrm{~m}$ elevation of the Zhengjiaping slope is locally covered by the accumulation of quaternary system. As shown in Figure 4, this study investigated the deformation quality of the Zhengjiaping slope by exploratory holes and eight site boreholes. The horizontal length of one exploratory borehole was $100 \mathrm{~m}$ and the investigation depth of the site borehole was $80 \mathrm{~m}$. The Zhengjiaping slope has strong and weak weathering zones, as well as noncorresponding strong and weak unloading zones, with intact fresh rock at depth. Figure 5 shows the attitude of slope surface, bedding plane, and major joints. Table 1 shows the volume content of the different lithologies, and Figure 6 shows the degree of weathering and unloading of the rock masses at different depths. 


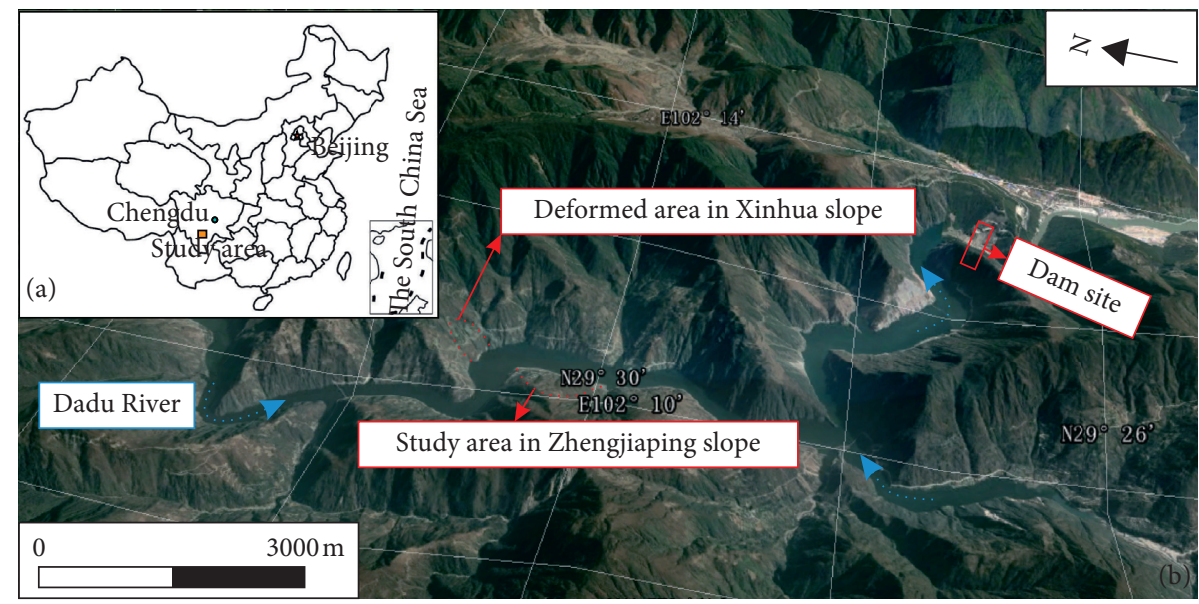

Figure 1: Site location of the Dagangshan Hydropower Station: (a) location of the Dagangshan reservoir and (b) the regional topographic map of the study area (from Google Earth, 2018).

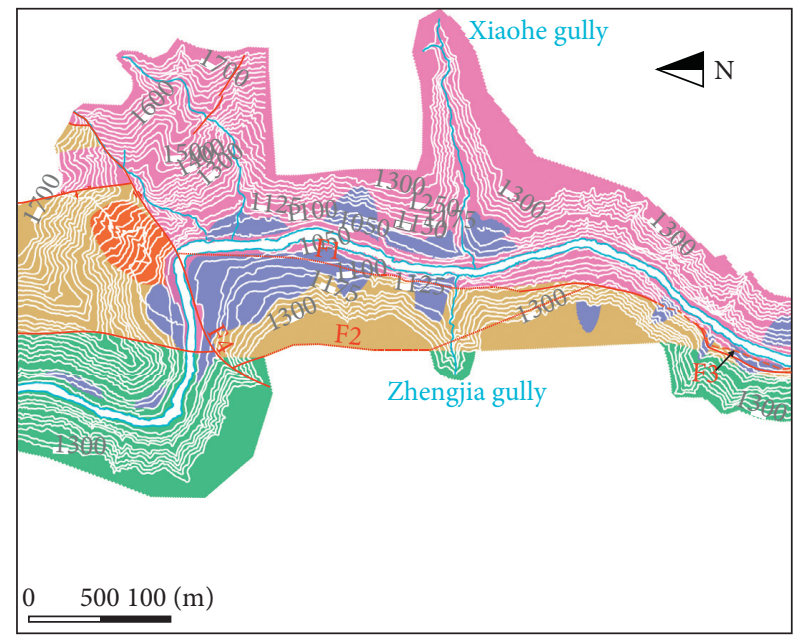

Granite in Chengjiang period

Sandstone and shale in Baiguowan formation

Metamorphic intrusive rock in Zhongtiao period

Accumulative formation in quaternary system

Slope deposits in Xinhua slope

(a)

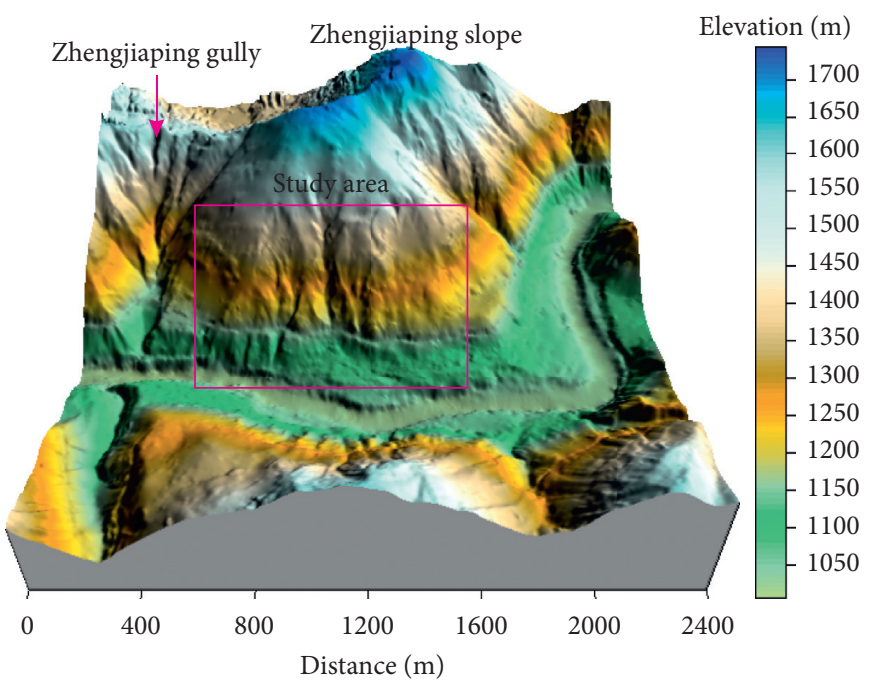

(b)

FIGURE 2: Geological conditions and topographic characteristics of the Zhengjiaping slope: (a) geological map of the Zhengjiaping slope and (b) three-dimensional visualization of the study area.

The impoundment in Dagangshan Hydropower Station began in May 2015. In October 2015, during the process of rising to normal water level, cracks were found in the middle and leading edge of the Zhengjiaping slope. By the end of February 2016, the width, number, and distribution range of cracks increased. In addition, a localized area of the Zhengjiaping slope has a more pronounced deformation in the 1100-1260 m elevation range. A number of cracks have been intermittently distributed along the back edge, extending about $100 \mathrm{~m}$ in length, $10-60 \mathrm{~cm}$ in width, and $20-50 \mathrm{~cm}$ in vertical offset. On both sides, cracks have a maximum crack aperture of $35 \mathrm{~cm}$ and a vertical offset of about $20 \mathrm{~cm}$. On 22 April 2016, a large number of bubbles were found emerging from the water surface of the reservoir near the upstream of the study area.

\section{Methods}

The distinct deformation zone of the Zhengjiaping slope extends from $1,125 \mathrm{~m}$ from the front elevation to $1,330 \mathrm{~m}$ from the back elevation along the direction orthogonal to the flow direction of the Dadu River. According to the different deformation characteristics, the study area can be divided into Zone I and Zone II. The volume of Zone I is about 


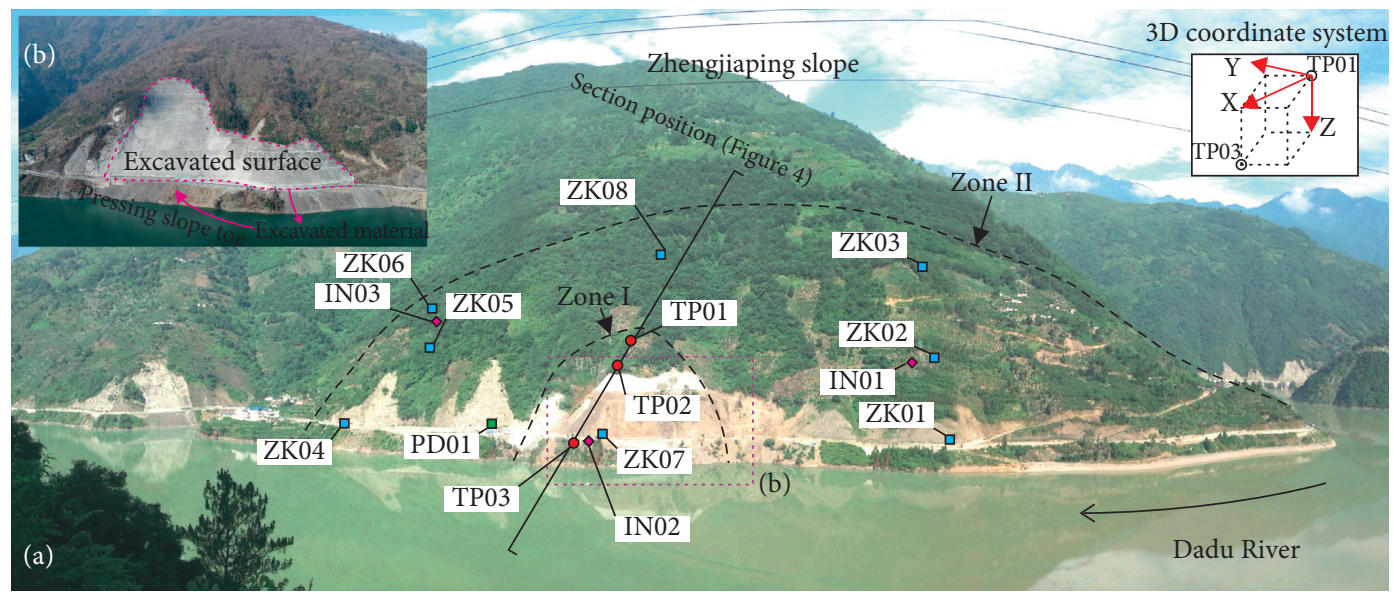

FIGURE 3: Overall view of the Zhengjiaping slope: (a) layout of exploratory adit, site boreholes, borehole inclinometers, and GNSS monitoring points and (b) postexcavation morphology and support measures. PD represents exploratory adit; ZK represents site boreholes; IN represents borehole inclinometers; and TP represents GNSS monitoring points.

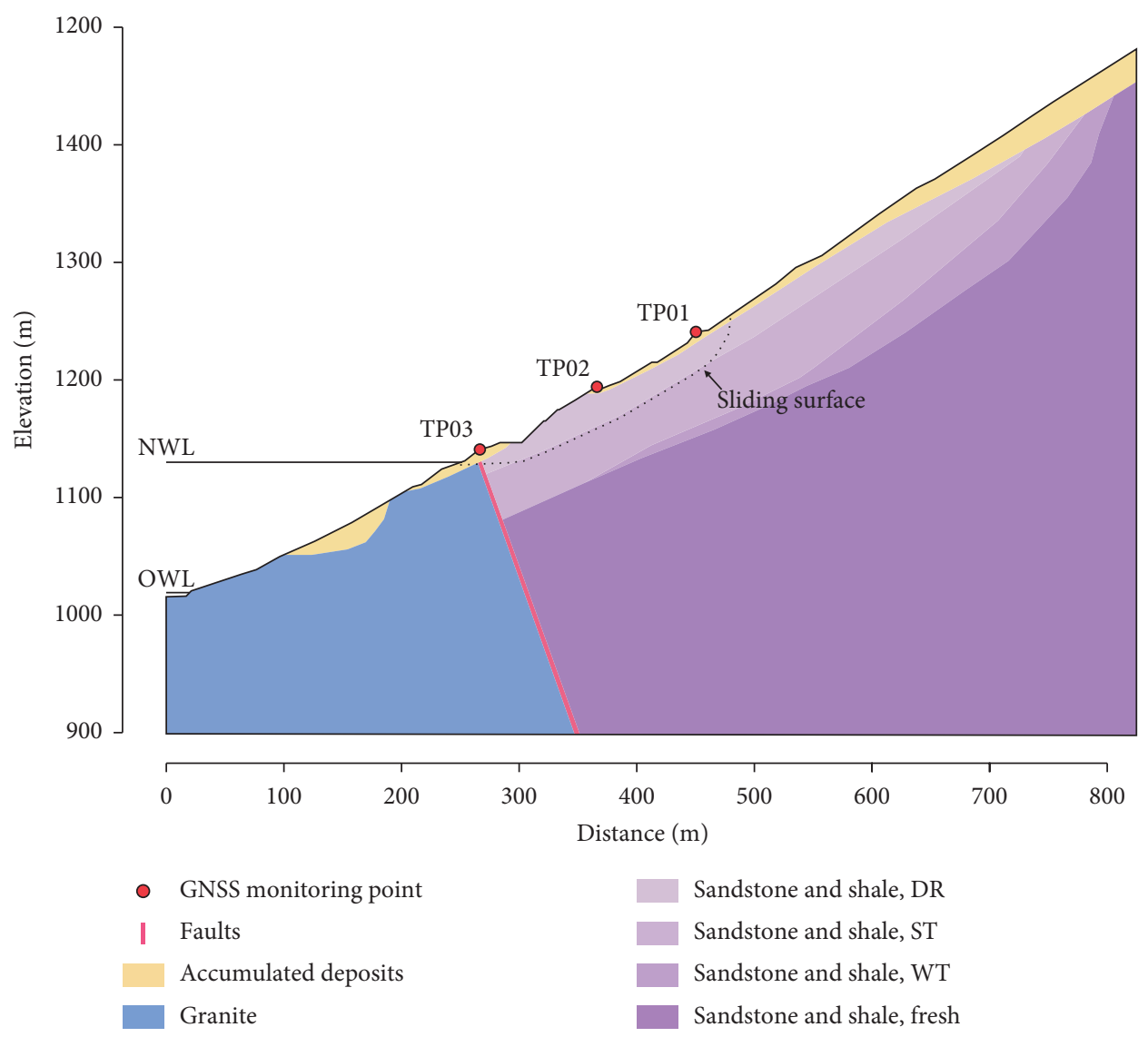

FIGURE 4: Geological profile of the selected location of the Zhengjiaping slope. NWL represents normal water level; OWL represents original water level; DR represents disintegration and relaxing deformation zone; ST represents strong toppling deformation zone; and WT represents weak toppling deformation zone.

$5 \times 10^{5} \mathrm{~m}^{3}$ and the volume of Zone II is about $1.5 \times 10^{6} \mathrm{~m}^{3}$. According to the geological background of the Zhengjiaping slope, the soil surface process and lithology of the obvious deformation zone are analyzed by field investigation and basic mechanical test. The deep lateral deformation monitoring operation was carried out using three borehole inclinometers (IN01-IN03). The Zhengjiaping slope point deformation monitoring operation was conducted using GNSS (Global Navigation Satellite System), including a continuously operating satellite positioning reference station 


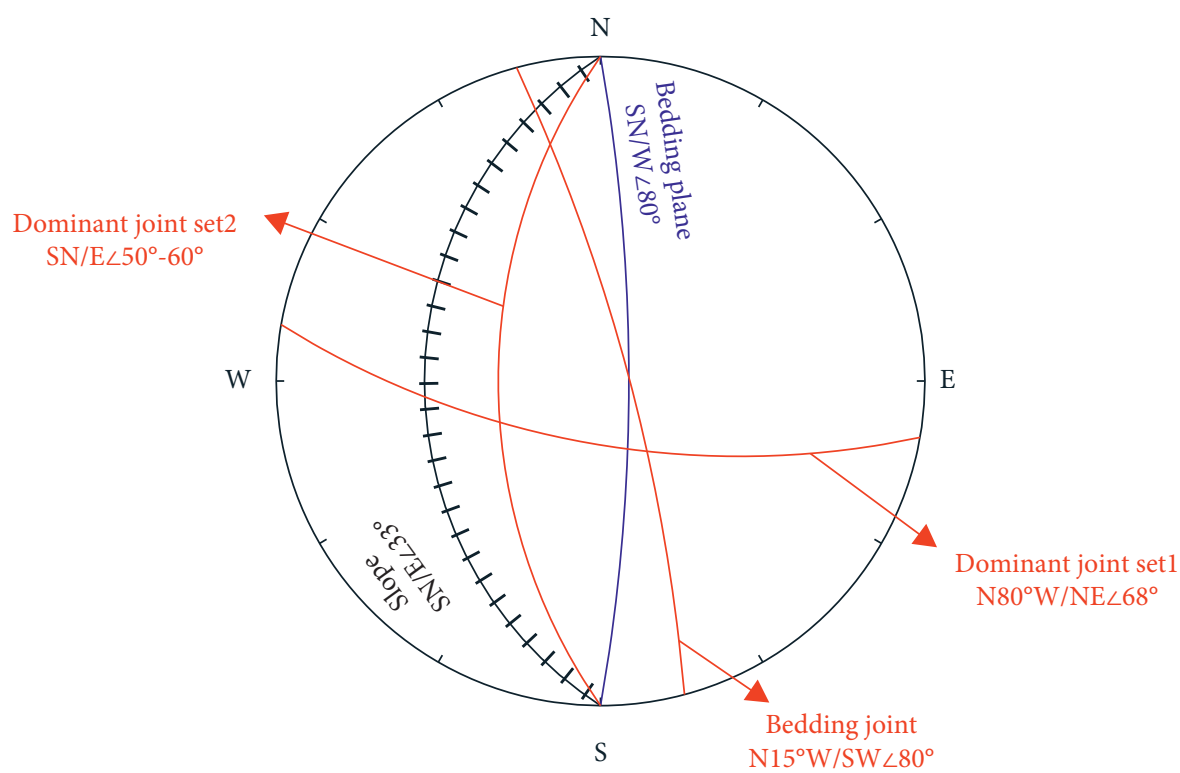

FIGURE 5: Stereonet with projections of the slope surface, bedding plane, bedding joint, and dominant joint sets.

TABLE 1: Statistical results of lithologic composition in different site boreholes on the Zhengjiaping slope.

\begin{tabular}{lcccccc}
\hline \multirow{2}{*}{ Exploratory point } & \multicolumn{2}{c}{ Argillaceous siltstone } & \multicolumn{2}{c}{ Sandstone } & \multicolumn{2}{c}{ Carbonaceous shale } \\
& Distributed length $(\mathrm{m})$ & Proportion & Distributed length $(\mathrm{m})$ & Proportion & Distributed length (m) & Proportion \\
\hline PD01 & 87.00 & 82.86 & 18.00 & 17.14 & - & - \\
ZK01 & 49.90 & 88.55 & 5.10 & 9.05 & 1.35 & 2.40 \\
ZK02 & 44.36 & 61.36 & 27.09 & 37.47 & 0.85 & 1.18 \\
ZK03 & 46.05 & 75.49 & 14.55 & 23.85 & 0.40 & 13.15 \\
ZK04 & 37.95 & 60.29 & 11.85 & 18.82 & 1.78 \\
ZK05 & 47.95 & 66.07 & 22.84 & 31.47 & 20.89 \\
ZK06 & 52.45 & 75.04 & 11.45 & 16.38 & 2.45 \\
ZK07 & 53.06 & 97.00 & 1.44 & 2.63 & 0.20 & 8.58 \\
ZK08 & 48.35 & 67.20 & 22.4 & 31.13 & 0.37 \\
\hline
\end{tabular}

and several deformation monitoring points. For better analysis of the monitoring data, a three-dimensional coordinate system was used, as shown in Figure 4.

\section{Results}

4.1. Earth Surface Processes. For the anaclinal slope, the soft plastic features of the rock masses and the thin stratified structure in the Baiguowan Formation favor the development of toppling deformation under long-term maximum principal stresses parallel to the slope surface $[41,42]$. Different processes of flexural toppling deformation of bedrock occur on the Zhengjiaping slope, which can be roughly divided into four categories: (1) the disintegration and relaxing deformation zone; (2) the strong toppling deformation zone; (3) the weak toppling deformation zone; and (4) the normal rock stratum zone (Table 2).

Disintegration and the relaxing deformation zone are mainly distributed in the shallow part of the Zhengjiaping slope at a depth of 6.6-46.25 m. As shown in Figure 7, rock stratum has a dip angle $0^{\circ}-20^{\circ}$, partly gently slope out. The deformation is characterized by strong tensile fracture. The fragmented relaxed rock mass has evidently internal hollow parts, which are filled with large pieces of block broken stones and breccia rock cuttings.

The distribution depths of the strong toppling deformation zone range from $6.6-46.25 \mathrm{~m}$. As shown in Figure 8(a), the stratified rock mass is characterized by strong tensile deformation between the bedding planes, and the extension-shear fracture surfaces of the cutting beds are commonly developed. The deformation behavior of the rocks in the strong toppling deformation zone is complex and can be summarized into three basic failure modes: intercalated shear sliding, discontinuous tensile fracture, and cut-bed tensile sliding (Figure 9). Intercalated shear sliding is a common phenomenon in schistosity planes and weak rock belts. Stratified rock masses with large dip angles have a tendency to dip out of the slope under bending moments from ground stresses, similar to cantilever beams. The flexural toppling deformations have a process of gradual development from the shallow part to the deep part, and the higher elevation causes the more intense deformation. In the local stratigraphy, tensile deformation occurs between the bedding planes under the high flexural toppling 


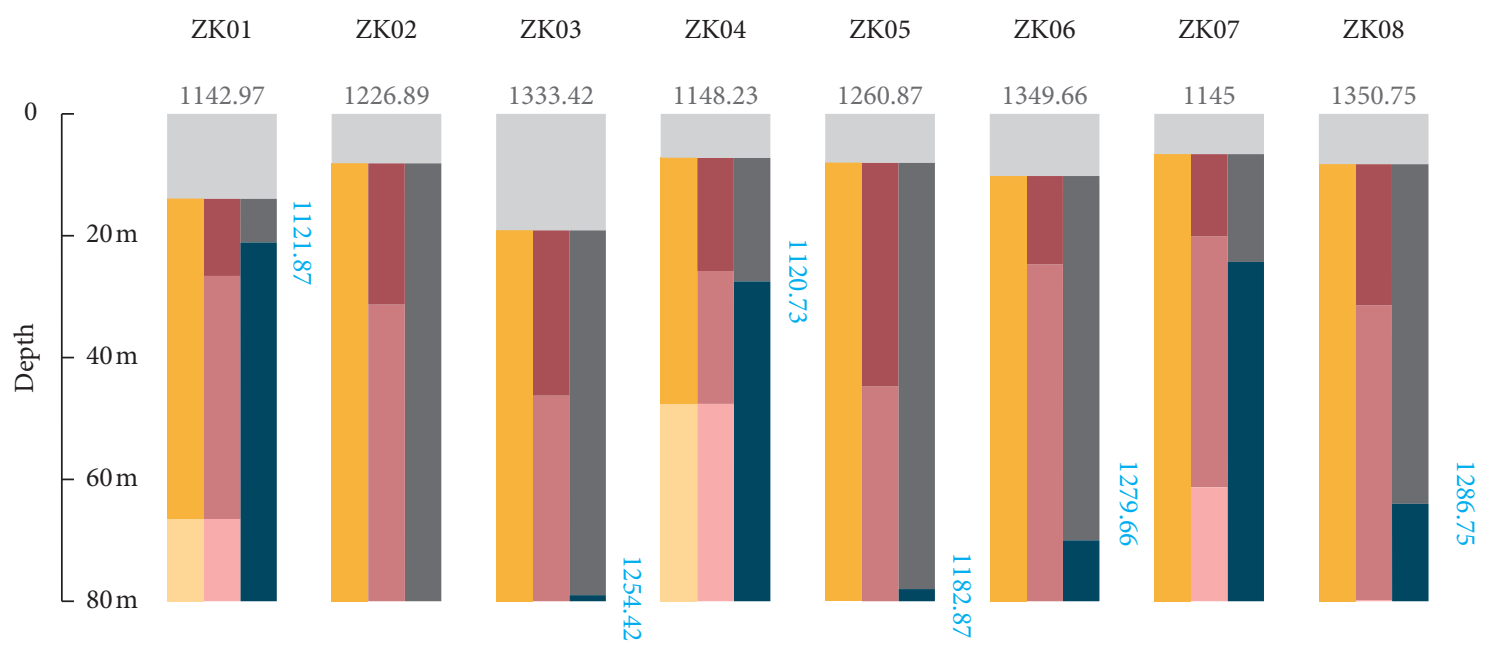

Overburden

Strong unloading

Weakly unloading

Strong weathered

Weakly weathered

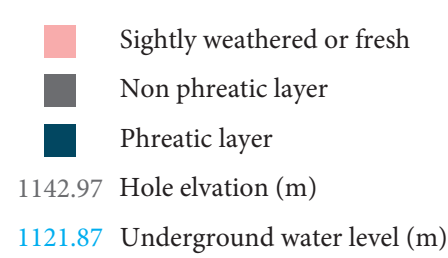

Figure 6: Vertical sequence of the unloading level and the weathered level, and the distribution of the underground water level in site boreholes.

TABLE 2: Distributing depth of the different partitions on the Zhengjiaping slope.

\begin{tabular}{|c|c|c|c|c|c|c|}
\hline $\begin{array}{l}\text { Exploratory } \\
\text { point }\end{array}$ & $\begin{array}{c}\text { Hole } \\
\text { elevation } \\
(\mathrm{m})\end{array}$ & Overburden & $\begin{array}{l}\text { Disintegration and } \\
\text { relaxing deformation zone }\end{array}$ & $\begin{array}{l}\text { Strong toppling } \\
\text { deformation zone }\end{array}$ & $\begin{array}{l}\text { Weakly toppling } \\
\text { deformation zone }\end{array}$ & $\begin{array}{l}\text { Normal rock } \\
\text { stratum zone }\end{array}$ \\
\hline PD01 & $1,145.00$ & - & $0-15$ & $15-80$ & 80-97 & $97-105$ \\
\hline ZK01 & $1,142.97$ & $0-13.9$ & $13.9-26.6$ & $26.6-66.5$ & $66.5-80.0$ & - \\
\hline ZK02 & $1,226.89$ & $0-8.1$ & $8.1-31.3$ & $31.3-66.8$ & $66.8-80.4$ & - \\
\hline ZK03 & $1,333.42$ & $0-19.1$ & $19.1-46.25$ & $46.25-80.1$ & - & - \\
\hline ZK04 & $1,148.23$ & $0-7.2$ & $7.2-25.8$ & $25.8-38.4$ & $38.4-47.6$ & $47.6-80.51$ \\
\hline ZK05 & $1,260.87$ & $0-8.0$ & $8.0-44.75$ & $44.75-80.57$ & - & - \\
\hline ZK06 & $1,350.00$ & $0-10.2$ & $10.2-24.7$ & $24.7-80.1$ & - & - \\
\hline ZK07 & $1,145.00$ & $0-6.6$ & $6.6-20.1$ & $20.1-61.3$ & $61.3-80.1$ & - \\
\hline ZK08 & $1,350.75$ & $0-8.25$ & $8.25-31.43$ & $31.43-79.8$ & $79.8-80.2$ & - \\
\hline
\end{tabular}

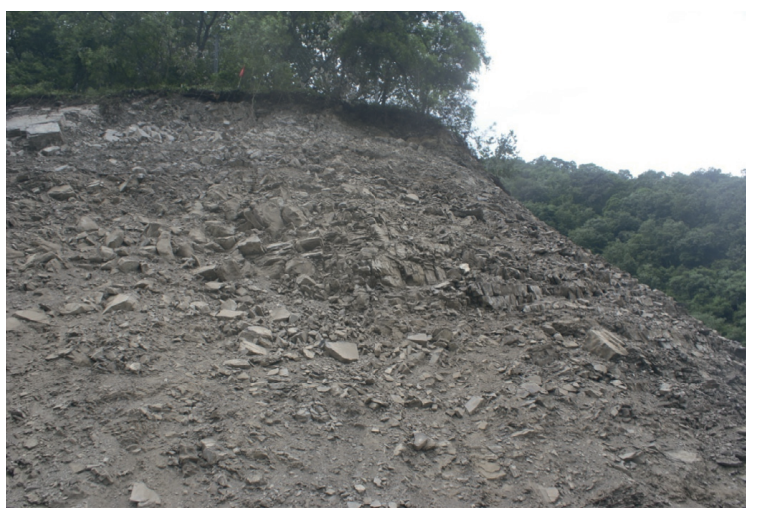

FIGURE 7: Photograph of the toppling deformation characteristics in the disintegration and relaxation of the deformation zone. deformation. As flexural toppling deformation develops, the level of toppling of the stratified rock mass is increasingly enhanced and the tensile stresses applied to the stratified rock mass are increasingly expanded. If the increased tensile stress reaches or exceeds the tensile strength, tensile fractures occur in the stratified rock mass accompanied by intercalated shear dislocations, resulting in discontinuous tensile fractures. When the development of toppling deformation is sufficient, the inclination of the deformed section changes considerably, the ground stress bending moment increases greatly, and the shear effect is greatly amplified. Under the joint action of shear and tension, cutting-bed tension sliding occurred on the deformed section.

Wedged cracks can be observed where there is evident toppling deformation, including the strong toppling deformation 


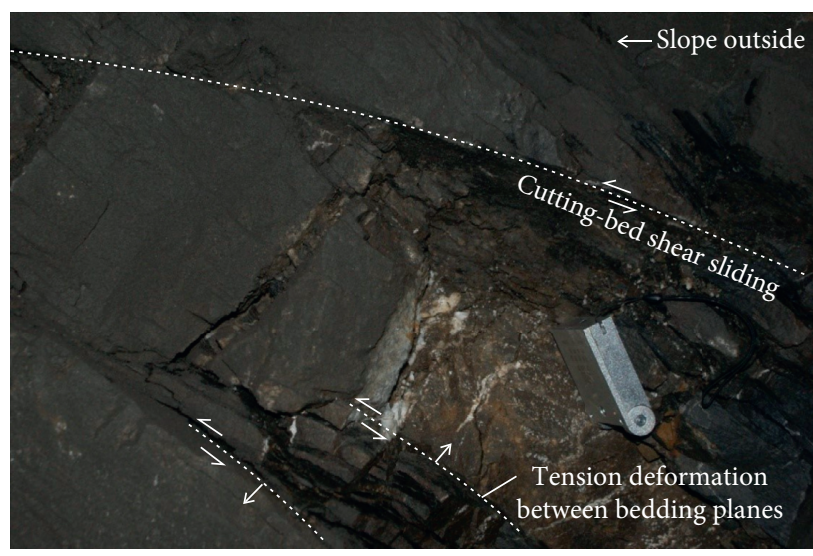

(a)

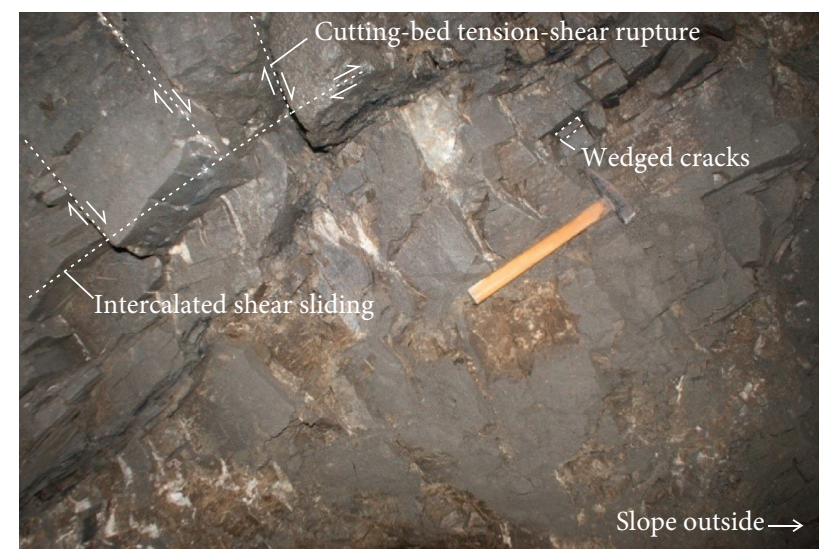

(b)

Figure 8: Photographs of the toppling deformation characteristics in the strong toppling deformation zone: (a) view of the cutting-bed shearing sliding and tension deformation between bedding planes and (b) view of intercalated shearing sliding.

zone and the weak toppling deformation zone. As shown in cracks. The weak toppling deformation zone is majorly
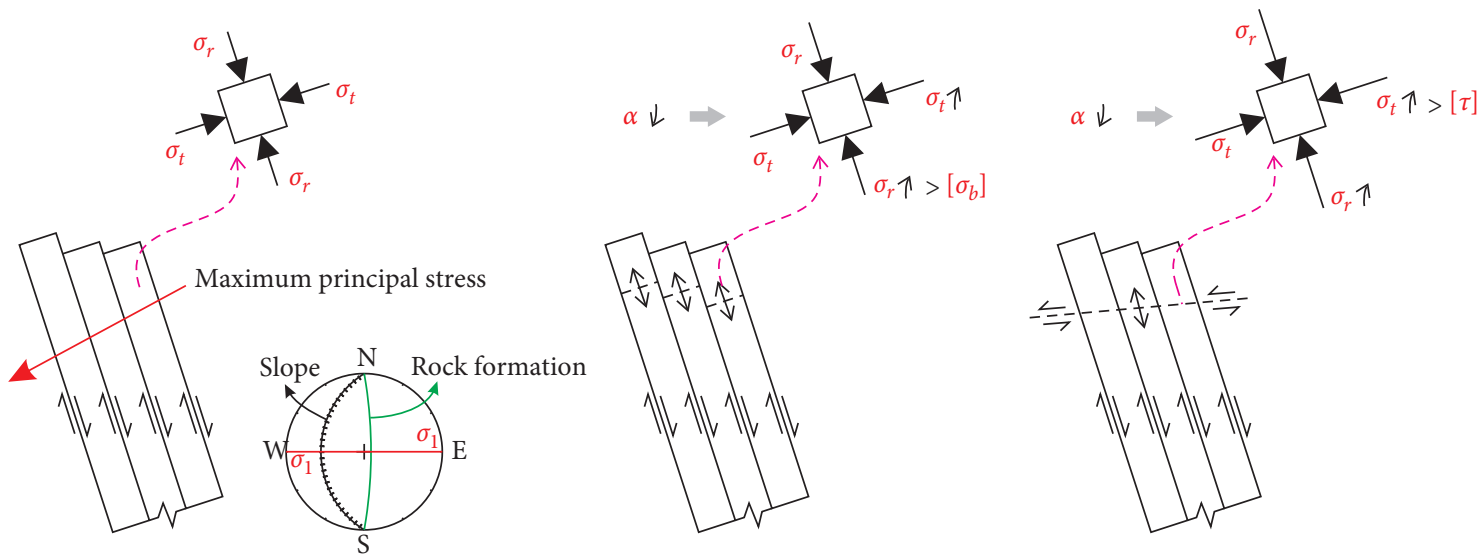

FIgURE 9: Schematic diagram of evolution process of the toppling deformation in the Zhengjiaping slope.

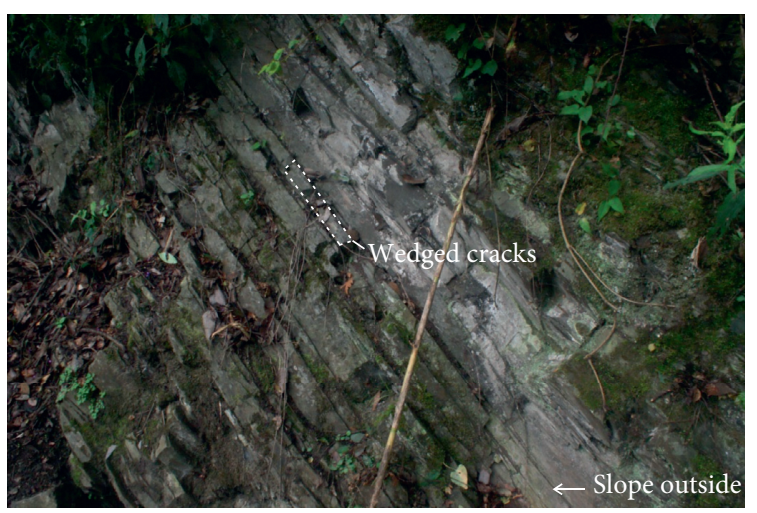

Figure 10: Photograph of the toppling deformation characteristics in the weak toppling deformation zone.

Figures 8 (b) and 10, the existence of intercalated shear sliding and discontinuous tensile rupture rebuild the morphology of the original intact bedrock and form wedged distributed in the deep part of the Zhengjiaping slope, with a depth more than $38.4 \mathrm{~m}$. This zone is characterized by the weak toppled level and slightly intercalated shear sliding with a dip direction of $40^{\circ}-60^{\circ}$. Because of the weak extension between bedding planes and the rare development of extension-shear fracture surfaces cutting the rock stratum, the stratified rock mass has a few tensile ruptures in the weak toppling deformation zone.

4.2. Deep Deformation. As shown in Figure 11, the data obtained by borehole inclinometers show lateral displacements of monitoring points for approximately half a year. As shown in Figure 4, the borehole inclinometers IN01 and IN03 were installed in Zone II, and IN02 was installed in Zone I. The evident deformation zone has a sliding surface of development with a depth of approximately $50 \mathrm{~m}$ on IN02 and several shearing dislocation zones of development on both borehole inclinometers. There are differences in the timing, number, and development of shear deformation 


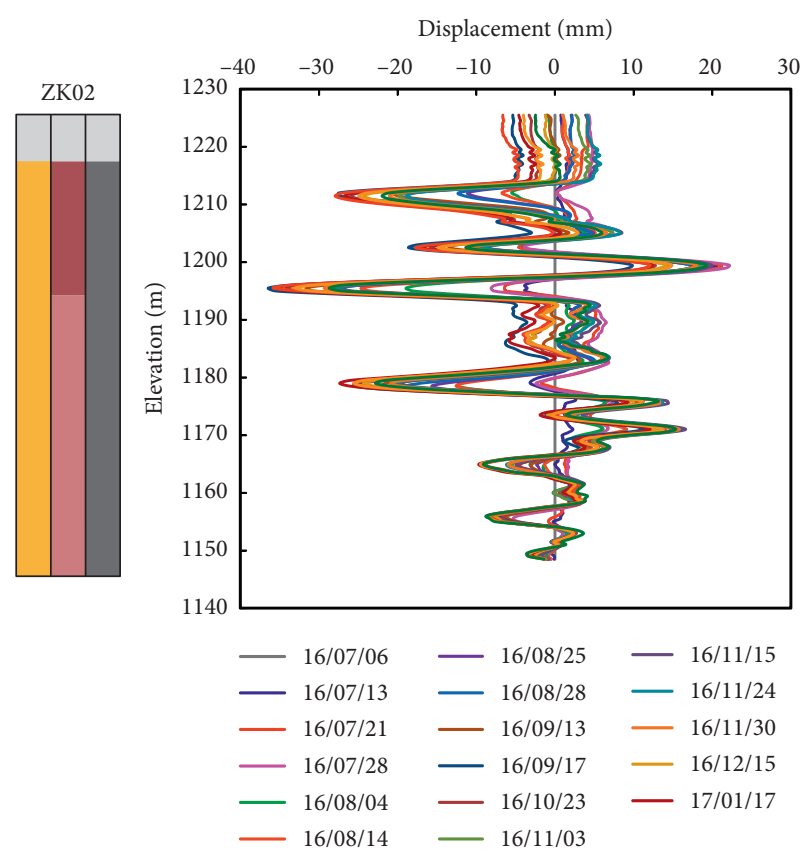

(a)

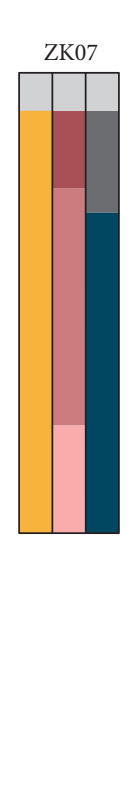

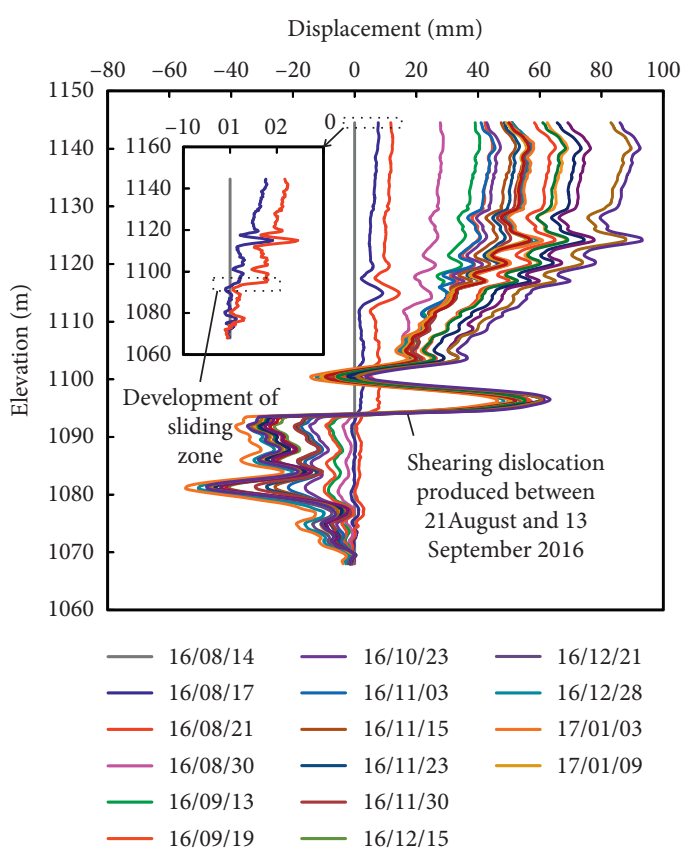

(b)

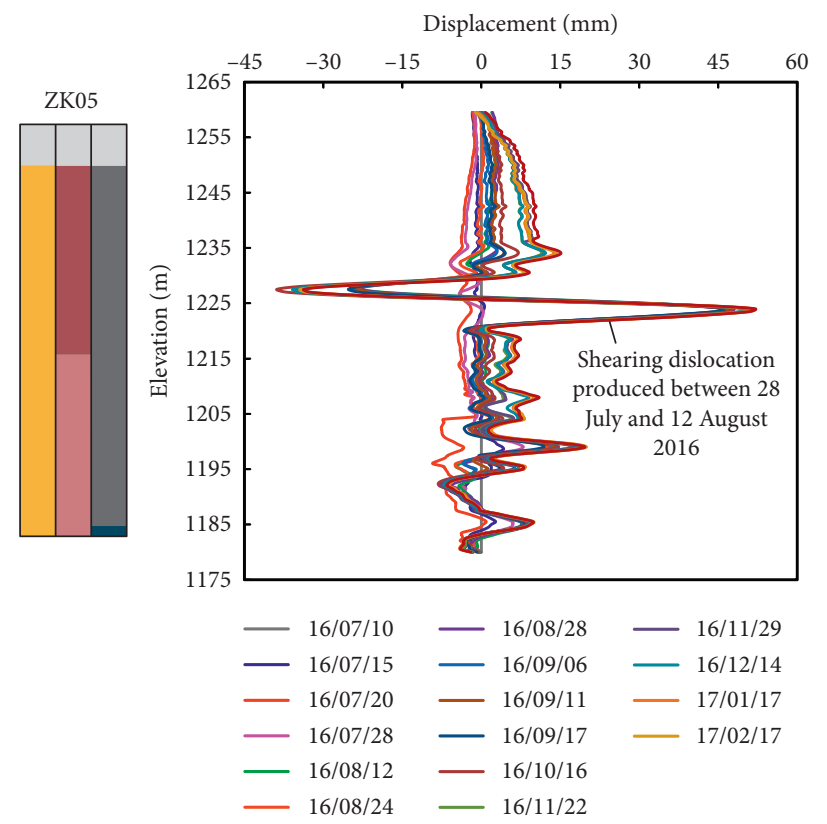

(c)

FIGURE 11: Time evolution of the lateral displacements for different monitoring points of the borehole inclinometer: (a) IN01; (b) IN02; and (c) IN03.

zones at the three borehole locations. The records of the borehole inclinometers indicate that the rock mass of Zone I actually participates in the sliding deformation. However, as can be seen in Table 3, the rock mass below $80 \mathrm{~m}$ depth is identified as a weak toppling deformation zone or a normal rock stratum zone, which makes it difficult to produce a sliding surface zone. Therefore, it is certain that the displacement of Zone I is characterized by a combination of sliding and toppling deformation processes that need to be focused on.
4.3. Slope Deformation. As shown in Figure 12, the monitoring data obtained by the GNSS have a record of accumulative displacements of monitoring points for approximately one and a half years. The preconstruction geological survey overlooked the potential of reservoir landslides in the Zhengjiaping slope. When the monitoring displacement began on 21 April 2016, it was approximately one year from the beginning of impoundment, and creep/ sliding deformations had already been occurring in the Zhengjiaping slope. Due to the late recording of the initial 
TABle 3: Toppling deformation characteristics of rock masses with different depths on the bank slope.

\begin{tabular}{|c|c|c|c|}
\hline Standard of classification & $\begin{array}{c}\text { Disintegration and relaxing } \\
\text { deformation zone }\end{array}$ & $\begin{array}{l}\text { Strong toppling deformation } \\
\text { zone }\end{array}$ & $\begin{array}{c}\text { Weak toppling deformation } \\
\text { zone }\end{array}$ \\
\hline Dip angle $\left({ }^{\circ}\right)$ & $0-20$ & $20-40$ & $40-60$ \\
\hline Variation of dip angle $\left({ }^{\circ}\right)$ & $50-70$ & $30-50$ & $15-30$ \\
\hline Maximum tensile length $(\mathrm{cm})$ & $5-20$ & $1-5$ & $<1$ \\
\hline $\begin{array}{l}\text { Unloading deformation } \\
\text { characteristics }\end{array}$ & Strong unloading, much relaxed & Strong unloading, relaxed & $\begin{array}{l}\text { Weak unloading, locally } \\
\text { relaxed }\end{array}$ \\
\hline Weathering degree & Strong weathered & $\begin{array}{l}\text { Strong weathered-weak } \\
\text { weathered }\end{array}$ & Weak weathered \\
\hline
\end{tabular}
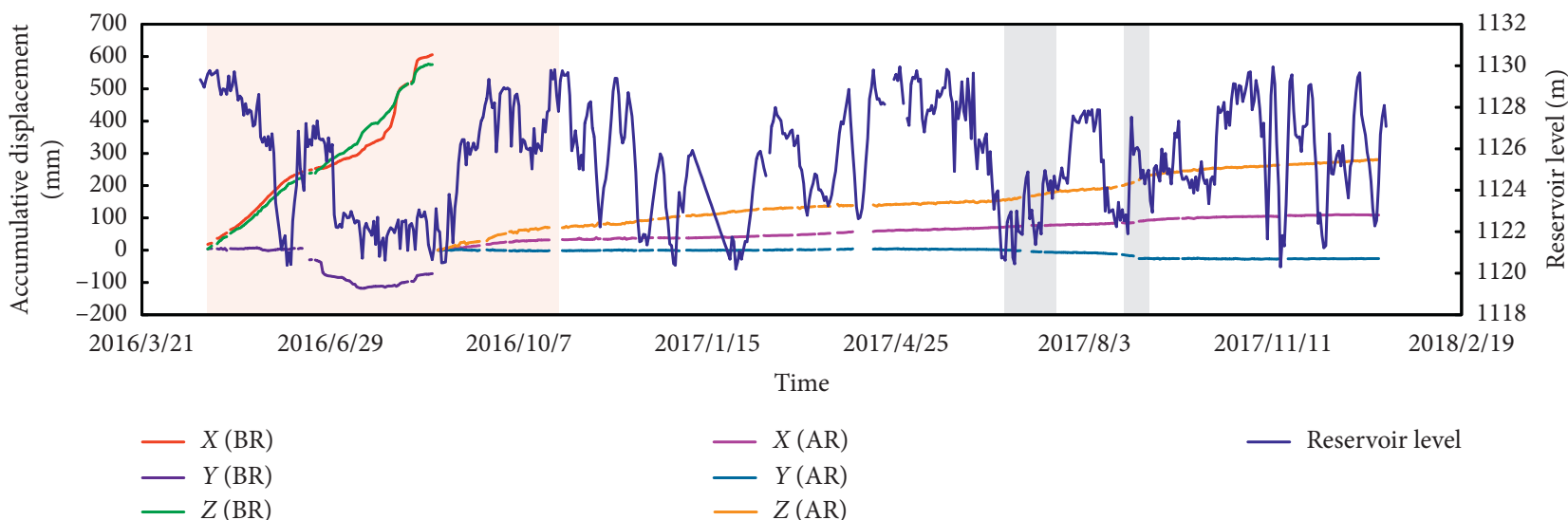

(a)

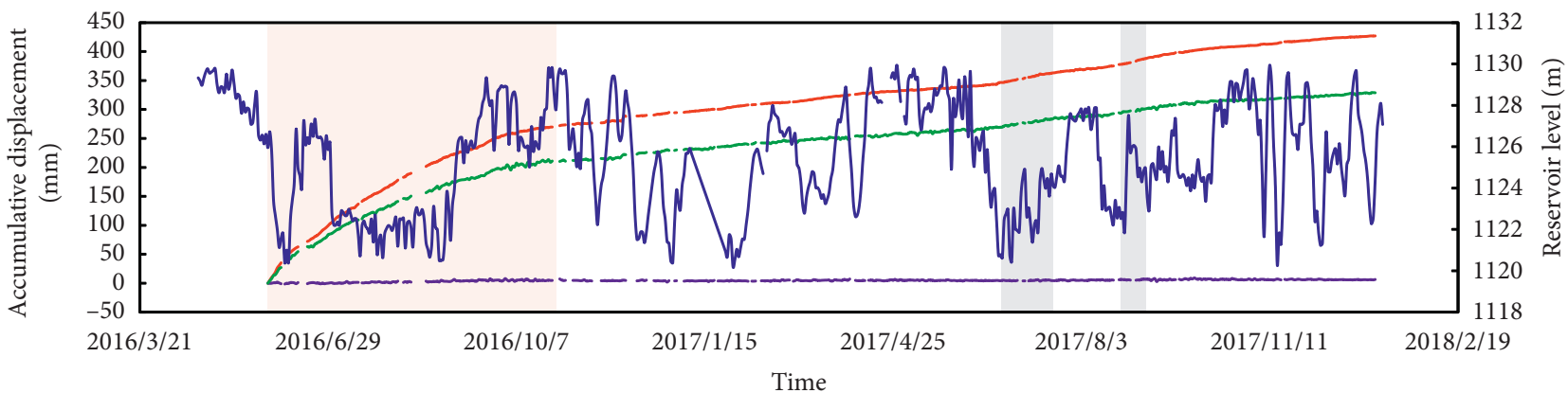

$X$
$-Y$

$-Z$

(b)
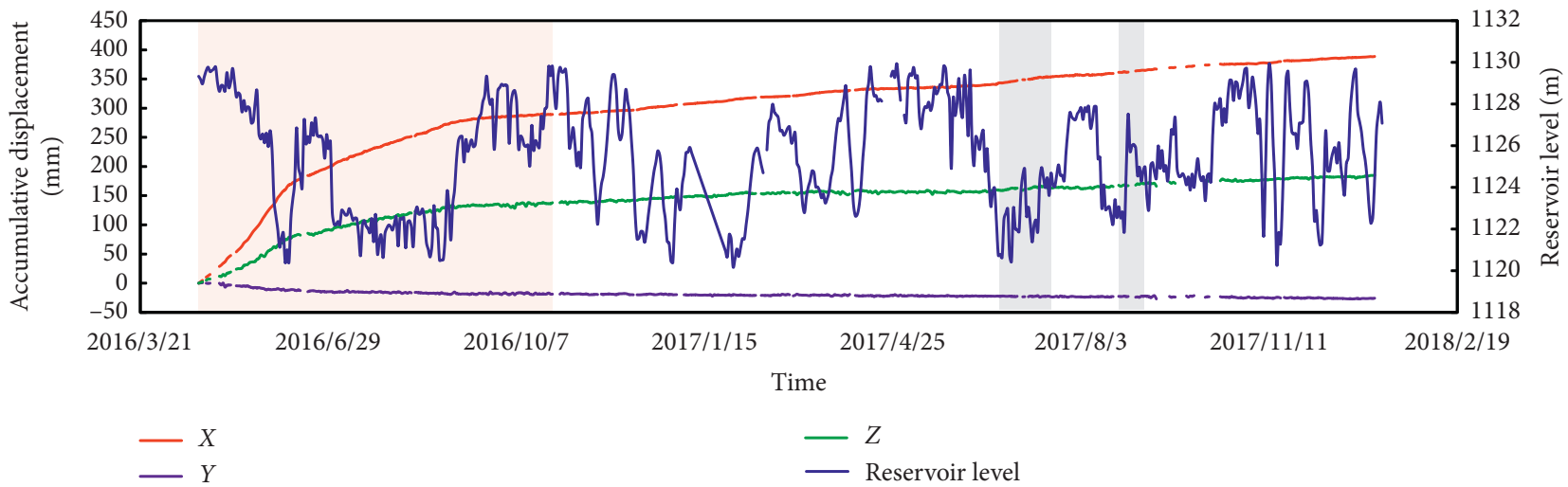

(c)

FIGURE 12: Time evolution of accumulative displacements in different directions for different monitoring points of GNSS in Zone I: (a) TP01; (b) TP02; and (c) TP03. 


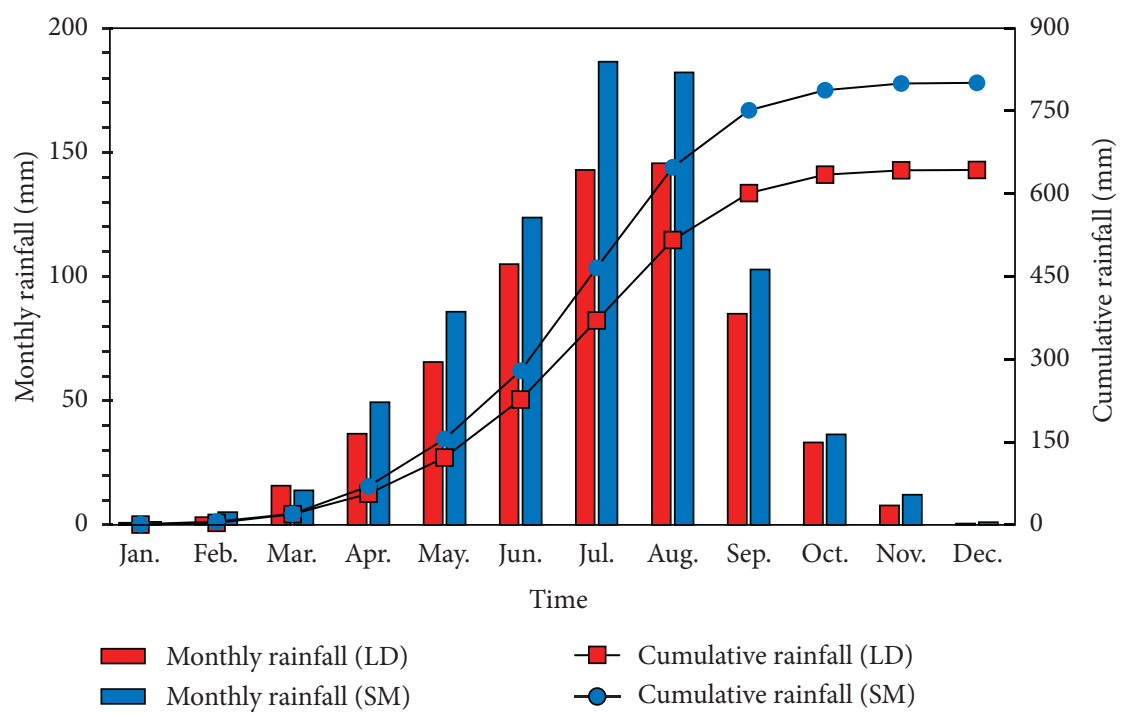

FIGURE 13: Precipitation records from two meteorological stations near the Dagangshan Hydropower Station (the data are mean annual values).

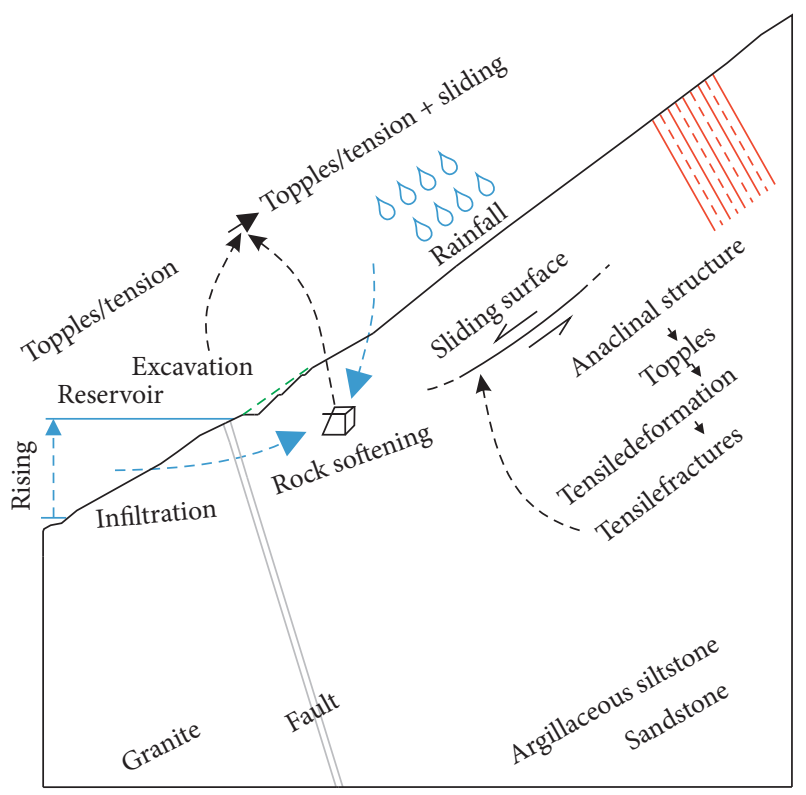

Figure 14: Mechanism of deformation development in the Zhengjiaping slope.

process of large deformation by the monitoring project, it is difficult to obtain a correlation between deformation and the contributing factors. At the same time, the Zhengjiaping slope was reinforced as it posed a great threat to traffic and residents' lives. Reinforcement was carried out from midMay to late August 2016, mainly targeting the excavated area in Zone I. Although the reinforcement had a restraining effect on the deformation of the Zhengjiaping slope, a continuous increase in cumulative displacement was still observed through GNSS.

Firstly, the temporal evolution of displacement and rainfall are compared. This is an oversight of the monitoring program that no rainfall measuring device is arranged in the range within $5 \mathrm{~km}$ of the targeted slope. There are two meteorological stations near the Dagangshan Hydropower Station. The Luding Meteorological Station has a distance of approximately $72 \mathrm{~km}$ from the upstream of the dam site and the Shimian Meteorological Station has a distance of approximately $40 \mathrm{~km}$ from the downstream of the dam site. As shown in Figure 13, the rainfall is mainly focused on a period from June to September, which accounts for $70-80 \%$ of the year's precipitation. It can be used as a reference for the rainfall characters for this case. The two mutations of displacement growths both happened in the flood season, that is, from June to September.

Then, the temporal evolutions of displacement and water level are compared. This two-year record can be superficially divided into two phases. The first phase is approximately from the beginning of deformation monitoring to $31 \mathrm{Oc}$ tober 2016, which was characterized by the gradually weakened growth of displacement. The drawdown of the reservoir level was presented in the early monitoring period, which presented the decrease in the deformation velocity, and the accumulative displacements still increased. In late August 2016, the reservoir level began to rise gradually, but the deformation velocities maintained a reducing trend. After that, the deformation velocities tended to be stable and kept a small value, which had little correlation to the changes of the reservoir level. After entering the second phase, the growth rate of displacements tended to be stable; only in two moments, there was an obvious mutation. There was a rise of water level in both displacement mutations. However, when the water level raised at other time, the growth rate of displacement had not been affected. However, the increase of accumulative displacements shows deceleration immediately because of the following drawdown of the reservoir level. As shown in Figure 12, the occurrence time of the increases in the two small-scale velocities is presented in the flood season with the frequent appearance of strong rainfall and increasing of water level. In conclusion, by using a monitoring analysis, impoundment and strong rainfall are 
TABLE 4: Summary of test results of mechanical property for the rock mass in the Zhengjiaping slope (the value is average level of test results).

\begin{tabular}{|c|c|c|c|c|c|c|c|c|c|}
\hline $\begin{array}{l}\text { Horizontal } \\
\text { depth of } \\
\text { sampling } \\
\text { location (m) }\end{array}$ & Lithology & $\begin{array}{c}\text { Dry } \\
\text { density } \\
\left(\mathrm{g} / \mathrm{cm}^{3}\right)\end{array}$ & $\begin{array}{l}\text { Specific } \\
\text { gravity }\end{array}$ & $\begin{array}{c}\text { Water } \\
\text { saturated } \\
\text { absorptivity } \\
(\%)\end{array}$ & $\begin{array}{c}\text { Dry } \\
\text { compressive } \\
\text { strength } \\
(\mathrm{MPa})\end{array}$ & $\begin{array}{l}\text { Saturated } \\
\text { compressive } \\
\text { strength } \\
(\mathrm{MPa})\end{array}$ & $\begin{array}{l}\text { Softening } \\
\text { coefficient }\end{array}$ & $\begin{array}{l}\text { Modulus } \\
\text { of } \\
\text { elasticity } \\
(\mathrm{GPa})\end{array}$ & $\begin{array}{l}\text { Poisson's } \\
\text { ratio }\end{array}$ \\
\hline 23 & $\begin{array}{l}\text { Argillaceous } \\
\text { siltstone }\end{array}$ & 2.65 & 2.68 & 0.30 & 85.77 & 70.33 & 0.82 & 31.43 & 0.23 \\
\hline 49 & $\begin{array}{l}\text { Argillaceous } \\
\text { siltstone }\end{array}$ & 2.67 & 2.69 & 0.27 & 110.93 & 90.80 & 0.82 & 36.00 & 0.23 \\
\hline 68 & Sandstone & 2.68 & 2.70 & 0.22 & 96.13 & 73.20 & 0.76 & 33.70 & 0.23 \\
\hline 76 & Sandstone & 2.57 & 2.60 & 0.47 & 48.30 & 33.70 & 0.70 & 24.33 & 0.27 \\
\hline
\end{tabular}

considered to be the major disaster-inducing factors for sliding deformation on the Zhengjiaping slope.

\section{Discussion and Conclusions}

Taking the Zhengjiaping slope as a research example, this paper analyzed the influence of geological conditions and water level on the anaclinal rock slope through field investigation and monitoring analysis. The study area of the Zhengjiaping slope is characterized by a fragmentized rock mass and a small amount of slope deposits. According to the difference in deformation characteristics, the study area can be divided into Zone I and Zone II. Since the impoundment, the deformation characteristics of the Zhengjiaping slope are toppling deformation, sliding deformation, and partial shallow collapse. Based on the degree of deformation and the identification of the sliding surface area, it was found that the sliding deformation only occurred in Zone I. The accumulative displacements on TP01, TP02, and TP03 had been $109 \mathrm{~mm}, 427.1 \mathrm{~mm}$, and $388.8 \mathrm{~mm}$, respectively, by the end of 6 January 2018.

As shown in Figure 14, the sliding deformation on the Zhengjiaping slope is an integration of many adverse factors. The hydrological activities, lithology, tectonic activities, and artificial disturbances, etc., make great contributions to the formation of the sliding mass and the sliding surface zone, for which a major performance assists in generating fragmentized rock mass in the shallow part. The Zhengjiaping slope has geological settings that are prone to toppling deformation under long-term maximum principal stress parallel to the slope surface. The main contents of the lithology in the sliding mass are sandstone and shale, which have low strength and lamellar structures with a large density of bedding surfaces, which aggravates the development of toppling deformation. Lithology is not the direct reason for the observed deformation after impoundment but has a specific lithologic distribution that ignores the potential for reservoir landslides in the early investigation. As shown in Figure 3(a), the region over the F1 Fault is characterized by argillaceous siltstone with intercalations of sandstone and carbonaceous shale, and the region below the F1 Fault is characterized by granite. The argillaceous siltstone, sandstone, and carbonaceous shale are different types of cementitious sedimentary rock. As shown in Table 4, the argillaceous siltstone and sandstone undergo a decrease in strength when they are saturated. When the water level rises significantly, the large volume of rock is immersed in the reservoir water, which in turn leads to a decrease in the shear capacity of the slope and a faster increase in displacement.

The effects of impoundment and strong rainfall directly cause the sliding deformation, which can be represented as both the physical and chemical actions of water on fragmentized rock mass. Monitoring analysis showed a correlation between the time series of displacement and reservoir water level, but it is not always observed. The phenomenon that the value of cumulative displacement was suffering the change of water level is only existed in the flood season. The evidence of these appearances suggests that both rainfall and water level changes are involved in the deformation. The infiltration of strong rainfall is aimed at a shallow part of sliding mass and sliding surface zone by a rear scarp. The influencing range of impoundment is referred to as the part of the sliding mass between the normal water level (the highest level of water that a reservoir can store under normal operating conditions) and the original water level (the level of the reservoir before the impoundment).

Artificial disturbance has both good and bad effects on slope stability. The good effects referred to the reinforcement on Zone I, which caused the cumulative displacements tend to be converged. The bad effects referred to the slope excavation in the reconstruction of the S211 road. First, the impact loads, which have been produced by the excavation work, cause the generation of new fractures and the extension of existing fractures. The development of fractures leads to a decrease in the rock strength around the excavation face. Second, excavation leads to a change in the distribution of stresses within the slope, which is detrimental to slope stability.

\section{Data Availability}

The data used to support the findings of this study are included within the article.

\section{Conflicts of Interest}

The authors declare that there are no conflicts of interest regarding the publication of this paper.

\section{Acknowledgments}

This work was supported by the National Key R\&D Program of China (2017YFC1501102), the National Natural Science Foundation of China (41977229), and the Sichuan Youth 
Science and Technology Innovation Research Team Project (2020JDTD0006).

\section{References}

[1] S. Qi, F. Yan, S. Wang, and R. Xu, "Characteristics, mechanism and development tendency of deformation of Maoping landslide after commission of Geheyan reservoir on the Qingjiang River, Hubei Province, China," Engineering Geology, vol. 86, no. 1, pp. 37-51, 2006.

[2] J.-W. Zhou, P.-Y. Lu, and Y.-C. Yang, "Reservoir landslides and its hazard effects for the hydropower station: a case study.," in Advancing Culture of Living with Landslides, M. Mikoš, Ž Arbanas, Eds., vol. 2, pp. 699-706, Springer International Publishing, Switzerland, 2017.

[3] J. Guo, M. Xu, and Y. Zhao, "Study on reactivation and deformation process of XierGuazi ancient-landslide in Heishui reservoir of southwestern China," Engineering Geology for Society and Territory, Springer International Publishing, vol. 2, pp. 1135-1141, 2015.

[4] J.-W. Zhou, F.-G. Xu, X.-G. Yang, Y.-C. Yang, and P.-Y. Lu, "Comprehensive analyses of the initiation and landslidegenerated wave processes of the 24 June 2015 Hongyanzi landslide at the three gorges reservoir, China," Landslides, vol. 13 , no. 3, pp. 589-601, 2016 a.

[5] R. M. Iverson, "Landslide triggering by rain infiltration," Water Resources Research, vol. 36, no. 7, pp. 1897-1910, 2000.

[6] D. Li, K. Yin, and C. Leo, "Analysis of baishuihe landslide influenced by the effects of reservoir water and rainfall," Environmental Earth Sciences, vol. 60, no. 4, pp. 677-687, 2010.

[7] Y.-Y. Jiao, H.-Q. Zhang, H.-M. Tang, X.-L. Zhang, A. C. Adoko, and H.-N. Tian, "Simulating the process of reservoir-impoundment-induced landslide using the extended DDA method," Engineering Geology, vol. 182, pp. 37-48, 2014.

[8] Q. Jiang, W. Wei, N. Xie, and C. Zhou, "Stability analysis and treatment of a reservoir landslide under impounding conditions: a case study," Environmental Earth Sciences, vol. 75, no. 1, 2016.

[9] Y. Yan, Y. Cui, X. Tian et al., "Seismic signal recognition and interpretation of the 2019 "7.23" Shuicheng landslide by seismogram stations," Landslides, vol. 17, no. 5, pp. 1191-1206, 2020.

[10] Y.-F. Cui, Y. Yan, G. Jian et al., "Landslide reconstruction using seismic signal characteristics and numerical simulations: case study of the 2017 "6.24" Xinmo landslide," Engineering Geology, vol. 270, Article ID 105582, 2020.

[11] D.-F. Macfarlane, "Observations and predictions of the behaviour of large, slow-moving landslides in schist, Clyde Dam reservoir, New Zealand," Engineering Geology, vol. 109, no. 12, pp. 5-15, 2009.

[12] R. Kumar and R. Anbalagan, "Landslide susceptibility mapping of the Tehri reservoir rim area using the weights of evidence method," Journal of Earth System Science, vol. 128, no. 6, Article ID 153, 2019.

[13] A. Kayabasi, "Evaluation of a reservoir landslide: a case study from Artvin, Turkey," Arabian Journal of Geosciences, vol. 13, no. 2, pp. 1-17, 2020.

[14] H.-A. Nefeslioglu and T. Gorum, "The use of landslide hazard maps to determine mitigation priorities in a dam reservoir and its protection area," Land Use Policy, vol. 91, Article ID 104363, 2020.
[15] Y. Zhang, X. Hu, D. D. Tannant, G. Zhang, and F. Tan, "Field monitoring and deformation characteristics of a landslide with piles in the three gorges reservoir area," Landslides, vol. 15, no. 3, pp. 581-592, 2018.

[16] G.-B. Crosta and F. Agliardi, "Failure forecast for large rock slides by surface displacement measurements," Canadian Geotechnical Journal, vol. 40, no. 1, pp. 171-191, 2003.

[17] L.-H. Blikra and L. Kristensen, "Monitoring concepts and requirements for large rockslides in Norway," Landslide Science and Practice, vol. 2, pp. 193-200, Springer Berlin Heidelberg, Heidelberg, Germany, 2013.

[18] L. Rouyet, L. Kristense, M.-H. Derron et al., "Evidence of rock slope breathing using ground-based InSAR," Geomorphology, vol. 289, pp. 152-169, 2017.

[19] T. Oppikofer, A. Saintot, R. L. Hermanns et al., "From incipient slope instability through slope deformation to catastrophic failure-different stages of failure development on the Ivasnasen and Vollan rock slopes (Western Norway)," Geomorphology, vol. 289, pp. 96-116, 2017.

[20] H.-B. Li, S.-C. Qi, X.-G. Yang, X.-W. Li, and J.-W. Zhou, "Geological survey and unstable rock block movement monitoring of a post-earthquake high rock slope using terrestrial laser scanning," Rock Mechanics and Rock Engineering, 2020.

[21] A. Pedrazzini, M. Jaboyedoff, C. R. Froese, C. W. Langenberg, and F. Moreno, "Structural analysis of turtle mountain: origin and influence of fractures in the development of rock slope failures," Geological Society, London, Special Publications, vol. 351, no. 1, pp. 163-183, 2011.

[22] Y.-X. Hu, H.-B. Li, S.-C. Qi, G. Fan, and J.-W. Zhou, "Granular effects on depositional processes of debris avalanches," KSCE Journal of Civil Engineering, vol. 24, no. 4, pp. 1116-1127, 2020.

[23] I.-M. Penna, A. Abellán, F. Humair, M. Jaboyedoff, S. Daicz, and L. Fauqué, "The role of tectonic deformation on rock avalanche occurrence in the pampeanas ranges, Argentina," Geomorphology, vol. 289, pp. 18-26, 2017.

[24] M.-D. Seta, C. Esposito, G.-M. Marmoni, S. Martino, G.-S. Mugnozza, and F. Troiani, "Morpho-structural evolution of the valley-slope systems and related implications on slope-scale gravitational processes: new results from the $\mathrm{mt}$. genzana case history (central apennines, Italy)," Geomorphology, vol. 289, pp. 60-77, 2017.

[25] Y.-X. Hu, Z.-Y. Yu, and J.-W. Zhou, "Numerical simulation of landslide-generated waves during the 11 October 2018 baige landslide at the Jinsha river," Landslides, 2020.

[26] G. F. Wieczorek and S. Jäger, "Triggering mechanisms and depositional rates of postglacial slope-movement processes in the Yosemite valley, California," Geomorphology, vol. 15, no. 1, pp. 17-31, 1996.

[27] M. Chigira and H. Yagi, "Geological and geomorphological characteristics of landslides triggered by the 2004 Mid Niigta prefecture earthquake in Japan," Engineering Geology, vol. 82, no. 4, pp. 202-221, 2006.

[28] J. Nyssen, J. Poesen, J. Moeyersons, J. Deckers, and M. Haile, "Processes and rates of rock fragment displacement on cliffs and scree slopes in an Amba, landscape, Ethiopia," Geomorphology, vol. 81, no. 3-4, pp. 265-275, 2006.

[29] D. Gu and D. Huang, "A complex rock topple-rock slide failure of an anaclinal rock slope in the Wu Gorge, Yangtze river, China," Engineering Geology, vol. 208, pp. 165-180, 2016.

[30] J.-W. Zhou, P. Cui, and M.-H. Hao, "Comprehensive analyses of the initiation and entrainment processes of the 2000 Yigong 
catastrophic landslide in Tibet, China," Landslides, vol. 13, no. 1, pp. 39-54, 2016.

[31] S. Assefa, A. Graziani, and A. Lembo-Fazio, "A slope movement in a complex rock formation: deformation measurements and dem modelling," Engineering Geology, vol. 219, pp. 74-91, 2017.

[32] S. Cui, X. Pei, and R. Huang, "Effects of geological and tectonic characteristics on the earthquake-triggered Daguangbao landslide, China," Landslides, vol. 15, no. 8, pp. 1-19, 2017.

[33] S. Hwang, I. F. Guevarra, and B. Yu, "Slope failure prediction using a decision tree: a case of engineered slopes in South Korea," Engineering Geology, vol. 104, no. 1-2, pp. 126-134, 2009.

[34] R. Khalokakaie and M. Zare Naghadehi, "The assessment of rock slope instability along the Khosh-Yeylagh main road (Iran) using a systems approach," Environmental Earth Sciences, vol. 67, no. 3, pp. 665-682, 2012.

[35] R. Fernandez-Rodriguez, C. Gonzalez-Nicieza, F. LopezGayarre, and E. Amor-Herrera, "Characterization of intensely jointed rock masses by means of in situ penetration tests," International Journal of Rock Mechanics and Mining Sciences, vol. 72, pp. 92-99, 2014.

[36] J. Zhang, H.-W. Huang, L.-M. Zhang, H.-H. Zhu, and B. Shi, "Probabilistic prediction of rainfall-induced slope failure using a mechanics-based model," Engineering Geology, vol. 168, no. 1, pp. 129-140, 2014.

[37] L. Nie, Z. Li, Y. Lv, and H. Wang, "A new prediction model for rock slope failure time: a case study in west open-pit mine, FuShun, China," Bulletin of Engineering Geology \& the Environment, vol. 76, no. 3, pp. 1-14, 2016.

[38] H. Fattahi, "Risk assessment and prediction of safety factor for circular failure slope using rock engineering systems," Environmental Earth Sciences, vol. 76, no. 5, Article ID 224, 2017.

[39] J.-W. Zhou, M.-Y. Jiao, H.-G. Xing, X.-G. Yang, and Y.-C. Yang, "A reliability analysis method for rock slope controlled by weak structural surface," Geosciences Journal, vol. 21, no. 3, pp. 1-15, 2017.

[40] D. M. Cruden, "Some forms of mountain peaks in the canadian rockies controlled by their rock structure," Quaternary International, vol. 68-71, no. 1, pp. 59-65, 2000.

[41] R.-E. Goodman, “Toppling of rock slope," Specialty Conference on Rock Engineering for Foundations and Slopes, vol. 2, pp. 201-234, 2017.

[42] Z. Zhang, G. Liu, S. Wu et al., "Rock slope deformation mechanism in the Cihaxia hydropower station, Northwest China," Bulletin of Engineering Geology \& the Environment, vol. 74, no. 3, pp. 943-958, 2015. 